CURRENT RESEARCH JOURNAL OF PEDAGOGICS 2(9): 123-129,

September 2021 DOI: https://doi.org/10.37547/pedagogics-crjp-02-09-28

ISSN 2767-3278

(C)2021 Master Journals

Crossref doi) 81 Google

Accepted 25 $5^{\text {th }}$ September, 2021 \& Published $30^{\text {th }}$ September, 2021

\title{
ELECTRONIC TEXTBOOKS: STRUCTURE AND CONTENT INTEGRATION
}

\section{Minavvarhon Sabirovna Yunusova}

Phd, Acting Associate Professor, Department Of General Science And Culture Tashkent State University Of Law, Uzbekistan

Jahongir Bakhodir Ugli Jurayev

Lecturer, Department Of General Science And Culture, Tashkent State University Of Law, Uzbekistan

\section{ABSTRACT}

Purpose. This article describes the formation of a hybrid form of an electronic textbook in legal education, the essence of online education, theoretical and practical foundations for the correct use of available sources of information for electronic textbooks.

Methodology. The article uses methods of source analysis, pedagogical experiment and comparative analysis to determine the advantages of an electronic textbook integrating search engines and open access sites.

Results. The problems of using electronic textbooks in legal education are analyzed. Studies, scientific works, experiments of foreign scientists have been studied and analyzed, and proposals for implementation in Uzbekistan are given. The existing systems are recommended for the implementation of the virtual environment in the management system of the legal education process.

Conclusion. From these results it is clear that with the help of these systems, students can achieve such qualities as the formation and development of research, information and professional competence.

KEYWORDS:- Electronic textbook, digital technology, virtual classes, e-sud, online education, cases, software tools, competence, information competence, research competence, systems.

\section{INTRODUCTION}

The development of information technologies gives an opportunity to develop new forms of their application in educational processes. It is impossible to imagine the learning without technology today and it is obviously that traditional methods are not interesting any more for both students and teachers. The most convenient form of teaching and learning is the use of electronic textbooks, that is, the use of software for teaching and determining the knowledge of students. The implementation of electronic textbooks can be viewed as a qualitatively new stage in the informatization of education.

An electronic textbook can be viewed as a product of intellectual capital. Intellectual capital consists of several parts (fig.1): human, organizational and consumer capital [1]. Human capital is that part of intellectual capital that is directly related to a person, and at the company level to its workforce. It includes knowledge, practical skills, creativity of people, their moral values and work culture [2]. Based on the description and structure, the electronic textbook can be divided into three parts. Human capital is knowledge, it means everything that is collected in theoretical and practical content in an electronic textbook, it is the capital of the 
CURRENT RESEARCH JOURNAL OF PEDAGOGICS 2(9): 123-129,

September 2021 DOI: https://doi.org/10.37547/pedagogics-crjp-02-09-28

ISSN 2767-3278

(C)2021 Master Journals

Crossref do: 81 Google

Accepted 25 $5^{\text {th }}$ September, 2021 \& Published 30 ${ }^{\text {th }}$ September, 2021

creator. Organizational capital is the hardware and software of the electronic textbook. Consumer capital, according to Kjell Nordström and Jonas Ridderstrale, is getting what you want «... real-time emotional and cultural needs of people, to extract the so-called "economies of soul" [1,3]. This means that in the process of education, students receiving knowledge through an electronic textbook should receive not only knowledge, but also cultural and emotional pleasure. For this, electronic textbooks should interest students as computer games. Since, playing computer games, they can sit for up to 56 hours, but learning from an electronic textbook, they do not study for more than 2-3 hours.
For legal education, it is advisable to use electronic textbooks online with the transition to the necessary sites or information systems during training. Electronic textbooks are created as a software tool, and the content in them becomes obsolete after a certain period of time. To prevent this from happening, the electronic textbook must have open content, and the information for the textbook must be available from websites and information systems. For the content of the electronic textbook, you need to select the resources corresponding to the curriculum.

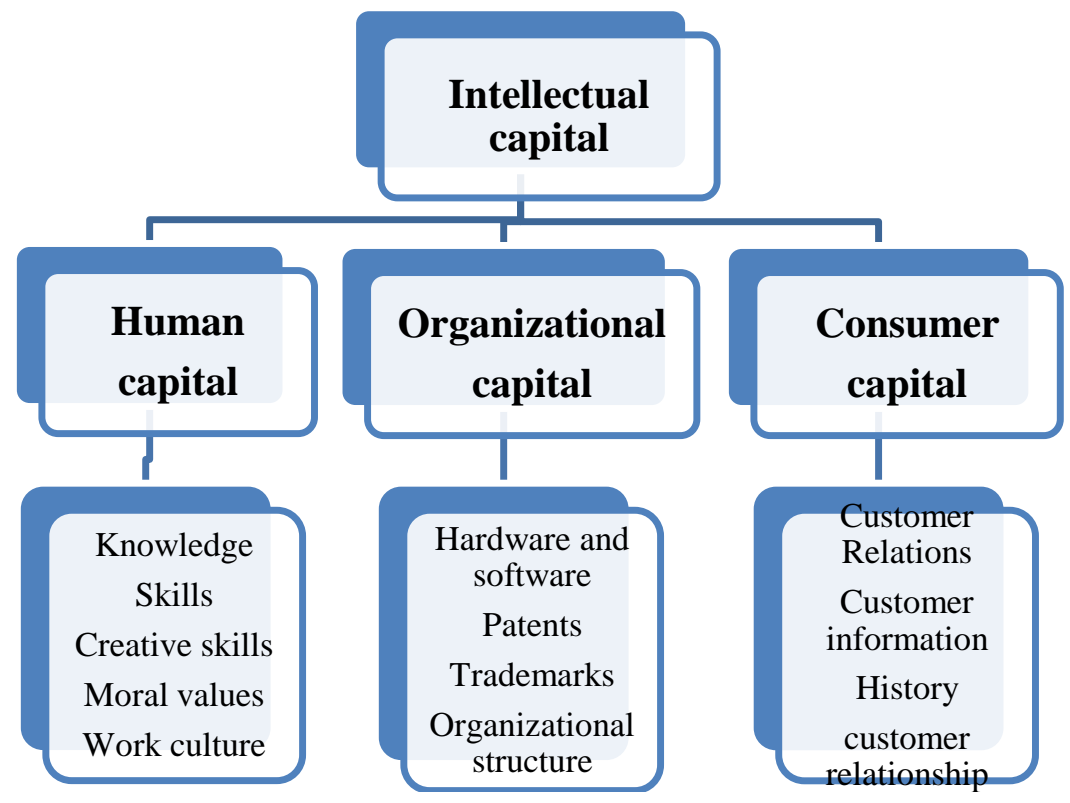

Figure 1. Intellectual capital structure

Created electronic textbook by our team written in the $\mathrm{C}$ \# language. During the studying process students can go to sites «E-sud», «Lex.uz» and
«Norma.uz» because these sites are used as main information sources by our university students. Furthermore, this e-book is created in cooperation with the information system «E- 
CURRENT RESEARCH JOURNAL OF PEDAGOGICS 2(9): 123-129,

September 2021 DOI: https://doi.org/10.37547/pedagogics-crjp-02-09-28

ISSN 2767-3278

(C)2021 Master Journals

Crossref dof 81 Google

Accepted 25th September, 2021 \& Published 30 ${ }^{\text {th }}$ September, 2021

sud» as a leading facilitator in the development of legal education and gives an opportunity to use its resources in learning process.

The transition to e-learning and its economic impact have been significant during the pandemic [8].

The structure of the electronic textbook has been changed. An electronic textbook integrated on legal search engines and open source sites.

Such a change in the structure of the e-textbook led to the appearance of a hybrid e-textbook. The e-textbook in hybrid form has the ability to work autonomously and at the same time use the information of the sites as content. When creating the content of the electronic textbook, the code for access to content on the Internet is written in the programming language $\mathrm{C} \mathrm{\#}$ as follows. Due to the availability of an electronic textbook for legal education, it is possible to access the website of national legal information retrieval systems and the national judicial system. The selected systems allow prospective lawyers to get acquainted with all normative documents and the procedure for applying to the courts. E-court allows you to use it as a virtual environment. The participation of students in an online open court session provides a realistic assessment.

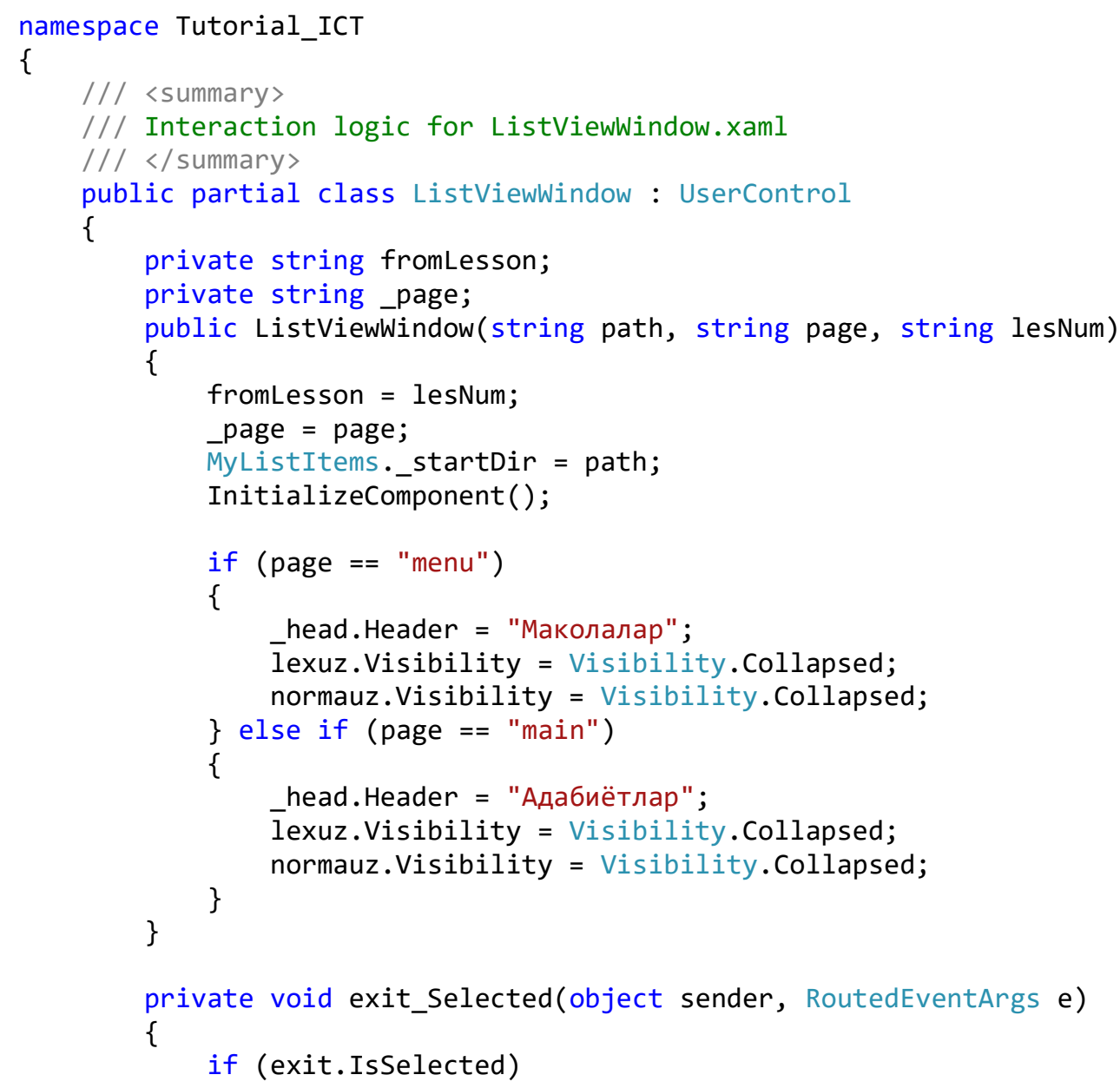


CURRENT RESEARCH JOURNAL OF PEDAGOGICS 2(9): 123-129,

September 2021 DOI: https://doi.org/10.37547/pedagogics-crjp-02-09-28

ISSN 2767-3278

(C)2021 Master Journals

\section{Crossref do) 81 Google}

Accepted 25th September, 2021 \& Published 30 ${ }^{\text {th }}$ September, 2021

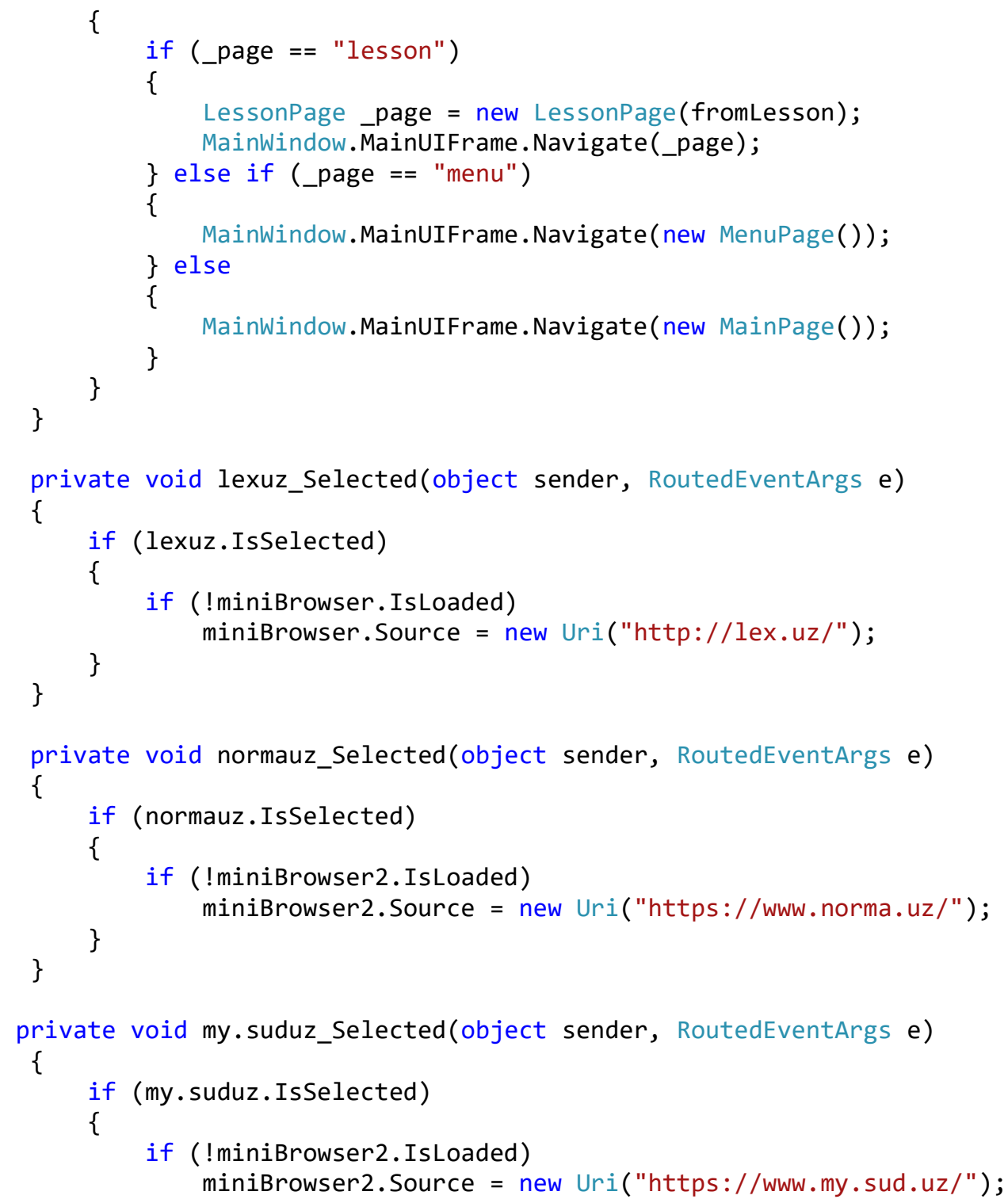

"E-sud" system is a kind of an alternative tool in improvement the practical skills of students and application of theoretical knowledge in the educational process. The module "Legal information technology" helps to improve knowledge of the information system on "E-sud" system. Furthermore, the online mode in the information system "E-sud" gives an opportunity to familiarize yourself with templates of appeals to economic courts, to present in online court sessions, and by playing the role of "judge's secretary" in a virtual environment, you can develop practical skills. Participation of students in specific litigation in real time not only enhances their knowledge and quality of the course, but also ensures that the judges make the 
CURRENT RESEARCH JOURNAL OF PEDAGOGICS 2(9): 123-129,

September 2021 DOI: https://doi.org/10.37547/pedagogics-crjp-02-09-28

ISSN 2767-3278

(C)2021 Master Journals

Crossref do: 81 Google

Accepted 25 $5^{\text {th }}$ September, 2021 \& Published 30 ${ }^{\text {th }}$ September, 2021

right decisions. Such lessons help to combine practice and theory, transparency both in education and in the courts.

The "E-sud" information system can be used as an example of a virtual classroom and virtual laboratory, which facilitate legal education. For this, the cooperation of systems is very important. This system serves as a supportive tool to enable students to become mature professionals ready for future work while studying. It was taught using an electronic textbook and a student mastery diagram was obtained.

\begin{tabular}{|c|c|c|c|c|}
\hline № & Legal systems & $\begin{array}{c}\text { Traditional } \\
\text { group }\end{array}$ & $\begin{array}{c}\text { Experiment } \\
\text { group }\end{array}$ & $\begin{array}{c}\text { Comparative } \\
\text { analysis } \\
\text { difference }\end{array}$ \\
\hline 1 & Lex.uz & $78 \%$ & $82 \%$ & $4 \%$ \\
\hline 2 & Norma.uz & $81 \%$ & $87 \%$ & $8 \%$ \\
\hline 3 & My.sud.uz & $86 \%$ & $94 \%$ & $8 \%$ \\
\hline 4 & e-notarius.uz & $75 \%$ & $76 \%$ & $1 \%$ \\
\hline 5 & advice.uz & $71 \%$ & $70 \%$ & $-1 \%$ \\
\hline 6 & davxizmat.uz & $83 \%$ & $85 \%$ & $2 \%$ \\
\hline 7 & Yuridik.uz & $72 \%$ & $73 \%$ & $1 \%$ \\
\hline
\end{tabular}

Table 1. Students' ability to work in legal systems

It was found that the speed of searching for the required normative documents from legal sources by e-textbook-trained groups was different from that of traditionally trained groups. The methods used to solve cases have also improved. The performance of students who were evaluated on the evaluation criteria formed before and after the experiment showed that the E-textbook system was effective (Table 1.). The result can be visualized through a diagram of students' ability to work in legal systems (Fig.2.). 
CURRENT RESEARCH JOURNAL OF PEDAGOGICS 2(9): 123-129,

September 2021 DOI: https://doi.org/10.37547/pedagogics-crjp-02-09-28

ISSN 2767-3278

(C)2021 Master Journals

Crossief do 80 Google

Accepted 25th September, 2021 \& Published 30 ${ }^{\text {th }}$ September, 2021

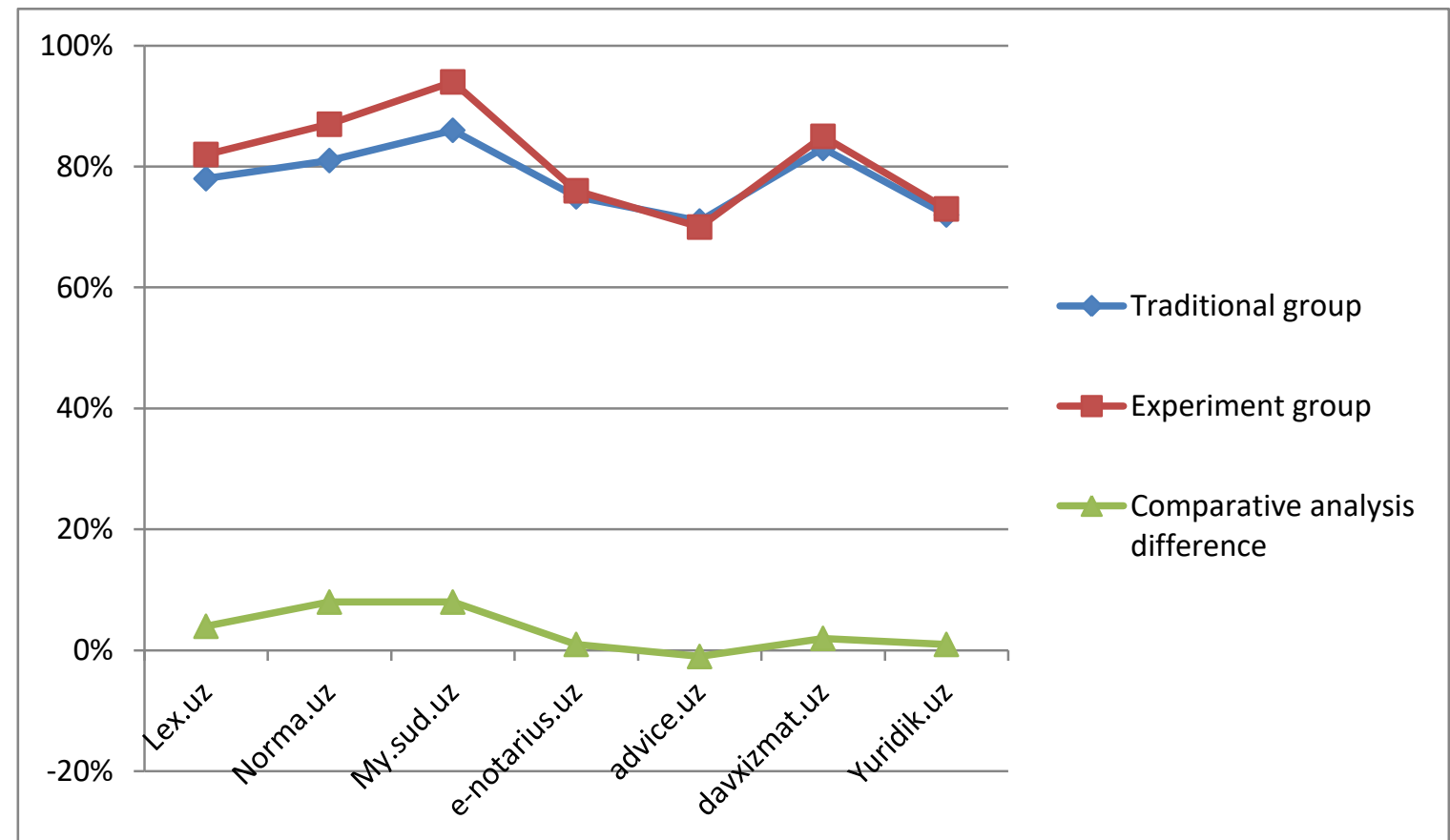

The groups in which the experiment was conducted and the groups in which the traditional study was conducted are presented the results of statistical analysis conducted by the method of Student Criterion (Table 2.) If we look at the difference in comparative analysis, the ability to work in legal systems not included in the e-textbook is almost no different from the traditional group and the experimental group.

\begin{tabular}{|l|l|c|c|c|}
\hline № & Stream and group & $\begin{array}{c}\text { Student critical } \\
\text { point } \\
t_{0.95}<T_{x y} \\
t_{0.95}(104)=1,97\end{array}$ & $\begin{array}{c}\text { Student Criteria } \\
T_{x, y}=\frac{/ \bar{X}-\bar{Y} /}{\sqrt{\frac{S_{x}^{2}}{n}+\frac{S_{y}^{2}}{m}}}=2,89\end{array}$ & $\begin{array}{c}\text { Degree } \\
\text { freedom }\end{array}$ \\
\hline 1 & A-stream group & 1,97 & 2,89 & 104 \\
\hline 2 & A-stream group & 1,97 & 2,92 & 100 \\
\hline 3 & B-sream group & 1,96 & 2,91 & 98 \\
\hline 4 & B-sream group & 1,97 & 2,81 & 101 \\
\hline 5 & V-stream group & 1,97 & 2,89 & 104 \\
\hline 6 & V-stream group & 1,97 & 2,92 & 100 \\
\hline
\end{tabular}


CURRENT RESEARCH JOURNAL OF PEDAGOGICS 2(9): 123-129,

September 2021 DOI: https://doi.org/10.37547/pedagogics-crjp-02-09-28

ISSN 2767-3278

(C)2021 Master Journals

\section{Crossref do) 8 Google}

Accepted 25 $5^{\text {th }}$ September, 2021 \& Published $30^{\text {th }}$ September, 2021

\section{Table 2. Statistical analysis of student outcomes}

\section{Conclusion}

In conclusion, the electronic textbook makes it possible to simplify the learning of law students [7] by using hyperlinks to information sources, for example, switch to the national database of legislation of the Republic of Uzbekistan "Lex.uz". From this site, the student can download or familiarize himself with the regulatory documents. In Uzbekistan there are several sites and information systems that can be used as educational resources like e-notarius.uz, davxizmat.uz and advice.uz, and through these electronic portals, it is possible to increase the interactivity and practicality of legal education. These systems should be integrated not only into electronic textbooks, but also into the educational process management system "Electronic University" [5] which is creating at the university. Thus, intellectual capital in education can provide real-time emotional and cultural needs for educators.

\section{REFERENCES}

1. Eremenko O.A. The main indicators for assessing intellectual capital//Modern scientific research and innovations. 2011. No. 2 [Electronic resource]. URL: http://web.snauka.ru/issues/2011/06/59 2 (access date: 21.12.2020).

2. Gaponenko A.L. Knowledge management//Moscow: IPK Civil Service, 2001.

3. Vladimir Karacharovsky / CNewsAnalytics // New challenges - new answers: intellectual capital through information technology - [Electronic resource] - Access link:

1. http://www.cnews.ru/reviews/free/indust ry2006/articles/capital.shtml.
4. Yunusova M.S. A new stage of introduction of artificial intelligence in society // Review of law sciences, 2020, - C 209-214

5. Маннопова Э.Т. Повышение конкурентоспособности высших образовательных учреждений за счет интеллектуальных информационных систем в управлении//Иқтисодиётда инновация. - 2020. - Т. 1. - №. 3.

6. Abduvakhidov A.M., \& Mannopova E.T. Theoretical approaches to formation of intelligent systems as a tool for providing management efficiency//Scientific studies on scientific-practical subjects, Tashkent. 2018. P.239-243.

7. Mannopova E.T. Reforms in education: information technology in the training of legal personnel//In The state has a wide range of information technologies and provides an exciting information for the republican scientific-conference conference. Tashkent. 2018. P.12-20.

8. Jurayev Jahongir Глобальный экономический кризис covid-19 и антикризисные меры (опыт ес ) // Review of law sciences. 2020. №Спецвыпуск. URL: https://cyberleninka.ru/article/n/covid19-global-iqtisodiy-inqirozi-va-ungaqarshi-choralar-yevropa-ittifoqi-tajribasi

9. Ismatullayeva, N. R. (2021). On the Introduction of E-Learning Portfolio in the Educational Process. Current Research Journal of Pedagogics (2767-3278), 2(09), 35-37. 